\title{
ON A SPECIES OF MICRODON FLY (DIPTERA) FROM NATAL.
}

\author{
By S. H. Skaife, M.A., M.Sc.
}

(With Plate XIII.)

The genus Microdon (Syrphidae) is remarkable for the aberrant nature of the habits and structure of the larvae. The majority of the species included in this genus are rare and little known, and in the case of only very few of these species are the larval, pupal and adult forms known. The larvae, in the few cases known, are tolerated guests, or synoeketes, of ants, and are mollusc-like creatures, more or less hemispherical in shape, and move slowly along on the flattened ventral surface. Their relationship to their hosts has never been ascertained, but it seems probable that they are scavengers, like the larvae of the nearly allied genus Volucella.

Bezzi, in his Syrphidae of the Ethiopian Region (1915), lists twenty species of Microdon from Africa, and of these some half a dozen are recorded from South Africa. He provisionally subdivides the genus into six groups, and the species described in this paper comprises his Group I. In Bezzi's work this subdivision includes only the one species, $M$. illucens, Bezzi, from Mozambique, a species which was founded on a single badly mutilated specimen. Nothing was known of the immature stages when Bezzi published his description. The present paper consists of a description of these stages together with a complete description of the adult.

A nearly full-grown larva was found on March 3, 1920, in an old bag of Acanthopsyche junodi, Heylaerts, at Mountain Rise, near Pietermaritzburg. The bag had been long vacated by its original owner, and was occupied, when found, by a small colony of the little black Dolichoderine ant, Technomyrmex albipes, Smith, race Foreli, Emery,* the Microdon larva being a guest of these ants. The ants and their guest were placed in a small Petri dish, together with a little honey and water to serve as food for the ants. The larva moved slowly about the nest and seemed to be totally ignored by its hosts. It apparently took no food, and there was very little refuse present on which it could feed. At the end of ten days it ceased moving about and its skin darkened somewhat in colour. On March 16, 1920, two small, chitinous horns were seen to be protruding from the anterior portion of the larva's body, thus marking the commencement of the pupal stage. On April 8, 1920, the adult emerged, after a pupal stage of twentythree days.

Description: Microdon illucens, Bezzi.

Larva. $-5-6 \mathrm{~mm}$. long $\times 3 \cdot 5-4 \mathrm{~mm}$. broad. Yellowish white in colour; 
no appearance of segmentation or of head. Covered on the dorsal region with a network of broken white lines made up of peculiar setae with flattened, stellate heads, with a narrow line, bare of setae, running longitudinally along the back; the border between the dorsal and ventral regions is armed with a narrow, inconspicuous fringe of peculiar, membranous hairs ; there is also a white, beaded line of setae running round this border. The terminal stigmata are very prominent, almost contiguous, and situated on a prominence having a conspicuous white periphery, the stigmata surrounded by brown, strongly chitinised lips.

Puparium.-Exactly the same as the larva, except for the presence of two prominent chitinous horns about a third of a millimetre in length, deep brown in colour, and situated at the anterior end of the dorsal region. Dehiscence occurs transversely along a line just posterior to these horns, the puparial skin bursting irregularly into three triangular pieces, the adult emerging through the opening thus made; there is no ptilinum.

Adult.-Length of body $8 \mathrm{~mm}$. Head wider than thorax, black, frons covered with conspicuous silvery pubescence, ocellar region bare; eyes fringed with silvery hairs; 1st joint of antennae longer than third, brown, 2nd joint short, terminal joint stout and blackish brown in colour. Thorax black, punctate, quadrate, thinly covered with a fine, greyish pubescence; a conspicuous band of golden-yellow hairs, broken in the middle, runs transversely across the thorax along the suture; a much less conspicuous band runs along the anterior border of the scutellum. Scutellum black, shining, rounded, armed with two small, curved, black spines. First segment of abdomen small, same width as the scutellum, black; 2nd elongated, constricted in the middle, black, with a narrow, yellow streak on each side, leaving in the centre a black median line broadening out anteriorly and posteriorly ; remainder of abdomen black, with a greenish sheen in strong light, covered thinly with a fine, greyish pubescence; 4th segment longer than 3rd or 5th; two conspicuous bands of golden yellow hairs run along the hind border of the 3rd and of the 4th segments. Four front legs testaceous, with fuscous femora; hind femora black, proximal half of hind tibiae white, distal half blackish brown, tarsi testaceous. Wings hyaline, except for slight infuscations along some of the veins, middle cross-vein situated on the basal third of the discal cell, third longitudinal vein provided with the usual peculiar stump in the subapical cell.

One specimen, a female, lodged in the S.A. Museum, Cape Town.

\section{EXPLANATION OF PLATE XIII.}

FIG.

a. Microdon illucens, Bezzi. $q \times 10$.

b. Microdon illucens, Bezzi. Larva. $\quad \times 8$.

c. Microdon illucens, Bezzi. Puparium, showing lines of dehiscence $(x) . \quad \times 8$. 


\section{$2 \mathrm{BHL}$ Biodiversity Heritage Library}

Skaife, S H . 1921. "ON A SPECIES OF MICRODON FLY (DIPTERA) FROM NATAL." Transactions of the Royal Society of South Africa 9, 221-222. https://doi.org/10.1080/00359192109520215.

View This Item Online: https://www.biodiversitylibrary.org/item/181591

DOI: https://doi.org/10.1080/00359192109520215

Permalink: https://www.biodiversitylibrary.org/partpdf/175613

\section{Holding Institution}

Smithsonian Libraries

\section{Sponsored by}

Biodiversity Heritage Library

\section{Copyright \& Reuse}

Copyright Status: Not in copyright. The BHL knows of no copyright restrictions on this item.

This document was created from content at the Biodiversity Heritage Library, the world's largest open access digital library for biodiversity literature and archives. Visit BHL at https://www.biodiversitylibrary.org. 